\title{
Study of Domino Number Game for Early Children's Ability to Recognize Numbers
}

\author{
Nur Ika Sari Rakhmawati ${ }^{凶}{ }^{1}$, Rachma Hasibuan ${ }^{2}$, Erni Lutfiyah ${ }^{3}$ \\ Pendidikan Guru Pendidikan Anak Usia Dini, Universitas Negeri Surabaya
}

\begin{abstract}
This study aims to develop and produce feasible and effective numerical domino game prototype used as learning to recognize symbols of number 1-10 for children aged 4-5 years. The design of study is research and development research adapted from Borg \& Gall research and development using Single one shot case study and One Pretest-Posttest Design Group. But the writers used only 9 steps. The subject in this study are Group A children aged 4-5 years in 6 kindergartens in Duduk sampeyan Subdistrict, Gresik District. Data were analyzed using descriptive quantitative. The results of this developmental research are numerical domino game prototype to develop 4-5 years old children's ability to recognize number 1-10. The operational field testing stage shows The average score is 0.84 , categorized as high. Therefore, it can be concluded that the numeric domino game is feasible and effective game used as learning to recognize the symbol of numbers 1-10 in children aged 4-5 years.
\end{abstract}

Keywords: number introduction, numeric domino game.

\begin{abstract}
Abstrak
Penelitian ini bertujuan untuk mengembangkan dan menghasilkan prototype produk permainan domino angka yang layak dan efektif digunakan sebagai pembelajaran mengenal lambang bilangan 1-10 pada anak usia 4-5 tahun. Jenis penelitian yang digunakan adalah penelitian pengembangan (research \& development) yang mengadaptasi dari langkah-langkah penelitian pengembangan Borg \& Gall. Namun dalam penelitian ini hanya menggunakan 9 tahap. Desain uji coba yang digunakan adalah Single One Shot Case Study dan One Group Pretest Posttest Design. Subjek uji coba penelitian adalah anak usia $4-5$ tahun pada 6 TK di kecamatan Duduk Sampeyan kabupaten Gresik. Analisis data menggunakan deskriptif kuantitatif. Hasil penelitian pengembangan ini berupa desain prototype permainan domino angka yang dapat mengembangkan lambang bilangan 1-10 pada anak usia 4-5 tahun. Hasil uji coba lapangan operasional diperoleh hasil penilaian yaitu mendapatkan kategori gain tinggi yaitu rata-rata 0.84. Sehingga dapat disimpulkan bahwa permainan domino angka sangat layak dan efektif digunakan untuk mengenalkan lambang bilangan 1-10 pada anak usia 4-5 tahun.
\end{abstract}

Keywords: pengenalan angka, permainan domino angka.

Copyright (c) 2019 Nur Ika Sari Rakhmawati, Rachma Hasibuan, Erni Lutfiyah

$\triangle$ Corresponding author :

Address : Jalan Lidah Wetan Lakarsantri Surabaya $60213 \quad$ ISSN 2356-1327 (Media Cetak)

Email : nurrakhmawati@unesa.ac.id

ISSN 2549-8959 (Media Online) 


\section{INTRODUCTION}

Early childhood is a unique and distinguished individual who have their own characteristics based on the age stage. Early childhood is ranged from the birth to 6 years. However, according to UNESCO \& UNICEF (2012) that early childhood is a child who is ranged from birth to 8 years old. Early childhood is a golden age so that it is very potential to train and develop a variety of their multi-intelligence.

According to Leeuwen (2010) childhood is the most critical period in cognitive and social development, language and early literacy. Because children are active from the beginning, early childhood education (PAUD) must be recognized as the first step of basic education integrated in the national education system. Early childhood education must provide learning to stimulate social, emotional, physical, cognitive development and language.

Kindergarten children aged 4-6 years are in a sensitive period, Montessori believes that children grow through sensitive periods where they will easily accept certain stimulations in their early years (Lillard, 2013). So, parents and teachers should guide and provide stimulation to develop children's potential optimally. Early childhood education can provide opportunities for children to develop all developmental aspects they naturally have such as physical motor development, religious morals, social-emotional, art, language as well as cognitive.

Children's cognitive development is how they develop thinking and expressing the opinions. States that all children have the same pattern of cognitive development through four stages: sensory-motor (age 0-2 years), preoperational (ages 2-7 year), concrete operations (ages 7-11 years), and formal operations for 11 years up. The children aged 4-5 years are classified in the pre-operational stage, and their cognitive development can be developed through activities because children can recognize some symbols. Therefore, Introducing number is very important to be taught for children as the basis for mastering the next mathematical concept at the next level of education.

However, many children aged 4-5 years still have the low ability to recognize symbols of numbers. Most children still make mistakes in mentioning the sequence of numbers 1-10. In addition, there are still children who are upside down in writing several symbols such as writing inverted numbers $3,4,5,6$, and 9 . Children sometimes still make mistakes in pointing symbols 1-10. Children still make mistakes when working on LKPD in connecting symbol numbers with objects 1 to 10 , especially images whose numbers are above 5 .

The problems happen because teachers often introduce numbers only through writing activities such as writing numbers $1,2,3$, etc in a checkered book. for some children, this is a boring activity where they only write the same number until they fill the book. In addition, children do not recognize the meaning of number only the symbols.

One of the problems was the limited method used by the teacher that resulted in low children's understanding to recognize number symbols. The learning process that can attract children's attention to learn is through playing in learning activities. Tatminingsih (2019) research results mention that comprehensive games can develop children's cognitive, but the teacher's role cannot be replaced by any media.

Anderson \& Bailey (2010) explains that The early childhood education emphasizes more on learning and playing activities meaning that every activity must be fun because by playing children will gain knowledge, learn to think, remember and solve problems. Kennedy \& Barblett (2010) adds that playing is an activity that children love, because playing makes them happy. Looking at the problem, it is necessary to learn through play and game activities. A similar study conducted by Fauziddin and Mufarizuddin (2018) states that the game of applause can develop children's cognitive.

The game gives children a pleasure. According to Docket \& Fleer (2000) through games, children can connect and develop 
knowledge. Numerical Domino Game is a fun game played with some rules and have certain goals as well. The game can also develop all aspects of children's development, and explore their potential. Research by Bergen (2002) states that role playing (pretending) is very influential on children's cognitive development.

If children do not have the opportunity to do the game, then the long-term capacity (memory) associated with metacognition, problem solving, social cognition, and academic fields such as recognizing letters, numbers of science, will certainly be hampered. Therefore, role playing (pretending) is very good for cognitive development because it involves the brain to work. Wang (2010) also explains that through board games, children can develop cognition in recognizing the numeric symbols. This board game is done in groups, where children can ask their friends something about mathematical concepts.

Numerical Domino game is adapted from domino game. The modifications are in use of tools, as well as rules. The tool used in this game is $3 \times 5 \mathrm{~cm}$ card and divided into two sides where symbols of numbers 1-10 is written. There are 66 cards used in playing the game. The rules are the players who have a same card (the same card) must issue the card as a sign to begin the game. The next player is required to release the cards in accordance with the symbol number presented on both sides of the card. If one player does not have a card offered, then the next player has the right to continue the game. The player is declared as the winner, if the player has used up all the cards. While the second, third and fourth players will count the remaining numbers. The player who holds the largest numbers is considered as loser. However, if each player's card cannot be issued, the winner is the one who has a card with a small number. This game is included in the modern game because the game uses the latest tools. This game is also included in an active game because children will be involved directly with tool. The purpose of this game is to introduce symbols of numbers 1-10 to children aged 4-5 years.

The previous research on Numerical Domino Game was conducted by Brankaer, et al. (2014), focuses to improve understanding of numbers in children with mild intellectual disability. The research conducted by Santos \& Alves (2000) also explains that through domino games, children can build their knowledge because when playing domino they are taught to recognize concepts, recognize rules, and interact directly.

However, writers in this study present the different numerical domino game tools from domino games in general and can be used as learning to improve the ability of children aged 4-5 years to recognize numbers1-10.

Based on the discussion, the research questions are as follows; 1) How is the feasibility of domino numbers playing with the ability to recognize 1-10 number symbols in children aged 4-5 years? 2) How does the effectiveness of domino numbers play with the ability to recognize numbers $1-10$ in 4-5 years old children?

\section{METHODOLOGY}

The design of study is research and development using Single one shot case study and One Pretest-Posttest Design Group. According to Creswell (2012) research and development is an approach that combines qualitative and quantitative designs. As well as Borg \& Gall (2003) states that educational research and development is a process used to develop and validate educational products.

The 10 steps arerefered to Borg \& Gall (2003) steps but the writers used only 9 steps including Research and information collecting, planning, develop preliminary form of product, preliminary field testing, main product revision, main field testing, operational product revision, operational field testing, final product revision 
Tabel 1. Research Steps

\begin{tabular}{|c|c|c|}
\hline No & Steps & Notes \\
\hline 1. & $\begin{array}{l}\text { Research and } \\
\text { information } \\
\text { collecting }\end{array}$ & $\begin{array}{l}\text { a. Doing needs analysis and } \\
\text { find a problem } \\
\text { b. Analyzing literature } \\
\text { review } \\
\text { c. Finding the solutions of } \\
\text { the problems }\end{array}$ \\
\hline 2. & Planning & $\begin{array}{l}\text { a. Analyzing the literature } \\
\text { reviewb. } \\
\text { b. Planning the learning } \\
\text { process } \\
\text { c. Arranging the game } \\
\text { steps }\end{array}$ \\
\hline 3. & $\begin{array}{l}\text { Preliminary } \\
\text { product } \\
\text { developement }\end{array}$ & \begin{tabular}{ll} 
a. & \multicolumn{2}{l}{ Formulating goals } \\
b. & Designing product \\
prototype & \\
c. & Setting product \\
& evaluation tools \\
& (validation instruments) \\
d. & Doing material and \\
media expert validation \\
e. & Final Product revision by \\
material and media \\
experts
\end{tabular} \\
\hline 4. & $\begin{array}{l}\text { Preliminary } \\
\text { field testing }\end{array}$ & $\begin{array}{l}\text { Doing the testing to get input } \\
\text { or suggestions for the } \\
\text { developed products }\end{array}$ \\
\hline 5. & $\begin{array}{l}\text { Main product } \\
\text { revision }\end{array}$ & $\begin{array}{l}\text { Making revisions to improve } \\
\text { the product }\end{array}$ \\
\hline 6. & $\begin{array}{l}\text { Main field } \\
\text { testing }\end{array}$ & $\begin{array}{l}\text { Retesting to know if the } \\
\text { product is ready or not. }\end{array}$ \\
\hline 7. & $\begin{array}{l}\text { Revisi produk } \\
\text { operasional }\end{array}$ & $\begin{array}{l}\text { Revising and evaluating } \\
\text { products }\end{array}$ \\
\hline 8. & $\begin{array}{l}\text { Operational } \\
\text { product } \\
\text { revision }\end{array}$ & $\begin{array}{l}\text { Testing the product } \\
\text { effectiveness }\end{array}$ \\
\hline 9. & $\begin{array}{l}\text { Operational } \\
\text { field testing }\end{array}$ & $\begin{array}{l}\text { Presenting final products as } \\
\text { learning for children }\end{array}$ \\
\hline
\end{tabular}

The Single One Shot Case Study and One Grup Pretest-Posttest Design is explained as follows (Creswell, 2012).

\section{Treatment Observation}

$$
\mathbf{O} \quad \mathbf{O}
$$

Figure 1. Single One Shot Case Study Design

Pretest

$$
\text { Treatment }
$$$$
\mathbf{X}
$$

\section{Figure 2. One Grup Pretest-Posttest Design}

The subject in this study are Group A children aged 4-5 years in 6 kindergartens in Duduk Sampeyan Subdistrict, Gresik District, consisting of; 11 children from TK DSP, 15 children from RA MNU 145, 15 children from
MNU RA 68, 14 children from MTK NU 231, 16 children from MNU TK 71, and 18 children from MNU MHS 119.

The research instrument data were numberical domino game prototype, learning activities planning set, observation sheets, validation sheets, interviews, and documentation. Data were analyzed using: (1) analysis of previous and main field testing using a single one shot case study; (2) data analysis of observation; (3) data analysis of the operational field testing using one group pretest and posttest design then analyzed by gain score and interpreted using a classification from Hake (1998); (4) data analysis of validation instrument; (5) data analysis of interview. The following is the formula gain score $\left(\mathrm{g}=\frac{\text { posttest-pretest score }}{\text { maximal-pretest score }}\right)$.

Tabel 2. Gain score (g) classification

\begin{tabular}{cc}
\hline Gain score & Category \\
\hline $\mathrm{G}>0.7$ & High \\
\hline $0.3<\mathrm{g} \leq 0.7$ & Moderate \\
\hline $\mathrm{G} \leq 0.3$ & Low \\
\hline
\end{tabular}

\section{RESULT AND DISCUSSION}

The research steps are adapted from Borg \& Gall (2003) research and developement design:

(1) The research and information collecting; The results show that children's cognitive abilities in recognizing the symbols of number are still low. When the teacher asked 25 children to sort the symbols of numbers $1-10$, but there were still 15 children who feel confused, 9 children who were still upside down in writing symbols number 3, 4, 5, 6 and 9 in their books, 18 children who were still wrong in showing the symbol numbers 1-10, and 20 children who misconnected the number symbols with objects more than 5 in number.

The observation and interview with classroom teachers were conducted to make preliminary conclusions. Then, it was found that the children got difficulty in recognizing the symbol of numbers because media and games were rarely used in learning process. Therefore, writers developed the numeric domino game. This game aimed to introduce symbols of numbers 1-10 in children aged 4-5 
years. This game is adapted from a domino game using a $3 \times 5 \mathrm{~cm}$ card that has 28 cards and a big round picture.

(2) The planning stage, the writers developed the numbers domino game products. This game uses a $3 \times 5 \mathrm{~cm}$ card divided into two sides. Each side has a number, including numbers 1-10. The cards used were 66 cards. In addition,the writers prepared the learning material, including mentioning the symbols of numbers 1-10, showing the symbols of numbers 1-10, pairing the symbol of the same number, and knowing the concept and not the symbol of number.

(3) The Preliminary product developement stage, the prototype of number domino game was designed and validated by material and media experts. Validation results were validation sheet, observation sheet, and the number of domino game activities.

(4) The Preliminary field testing stage, it was done at the TK DSP with 11 children. The field testing was conducted by teachers using a treatment in the form of a number domino game, the researcher was observing the child using checklist. The results of The field testing can be seen in table 3:

Table 3. The Result of Primeraliy Field Testing In TK DSP

\begin{tabular}{|c|c|c|c|c|c|c|c|c|c|}
\hline \multirow{2}{*}{$\begin{array}{l}N \\
0\end{array}$} & \multirow[t]{2}{*}{ Indicators } & \multicolumn{4}{|c|}{$\begin{array}{c}\text { Students' } \\
\text { scoring }\end{array}$} & \multicolumn{4}{|c|}{ Presentage } \\
\hline & & 1 & 2 & 3 & 4 & 4 & 3 & 2 & 1 \\
\hline 1 & $\begin{array}{l}\text { Children } \\
\text { can name } \\
\text { the } \\
\text { symbol } \\
\text { sequently } \\
\text { from } \\
\text { numbers } \\
1-10\end{array}$ & 11 & - & - & - & $\begin{array}{c}100 \\
\%\end{array}$ & - & - & - \\
\hline 2 & $\begin{array}{l}\text { Children } \\
\text { can show } \\
\text { symbols } \\
\text { of number } \\
1-10\end{array}$ & 7 & 3 & - & 1 & $\begin{array}{c}63.6 \\
\%\end{array}$ & $\begin{array}{c}27.2 \\
\%\end{array}$ & - & $\begin{array}{l}9 \\
\%\end{array}$ \\
\hline 3 & $\begin{array}{l}\text { Children } \\
\text { can pair } \\
\text { the same } \\
\text { number } \\
\text { symbol }\end{array}$ & 5 & 6 & - & - & $\begin{array}{c}45.4 \\
\%\end{array}$ & $\begin{array}{c}54.5 \\
\%\end{array}$ & - & - \\
\hline 4 & $\begin{array}{l}\text { Children } \\
\text { can } \\
\text { mention } \\
\text { different } \\
\text { symbols } \\
\text { of } \\
\text { numbers }\end{array}$ & 7 & 3 & 1 & - & $\begin{array}{c}63.6 \\
\%\end{array}$ & $\begin{array}{c}27.2 \\
\%\end{array}$ & $\begin{array}{l}9 \\
\%\end{array}$ & - \\
\hline
\end{tabular}

Source : processed data

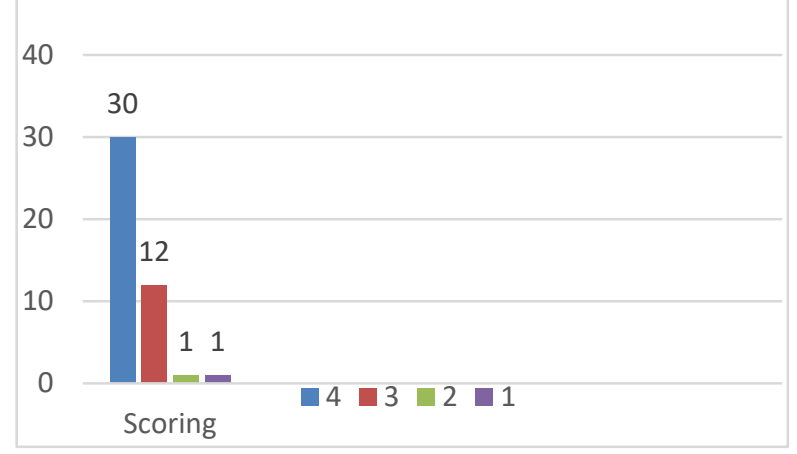

Graph 1. Observation Result of Numeric Domino Number game in TK DSP

The result of preliminary field testing shows that Numeric domino game is feasible to use. Children after using the game can recognize the symbols of number 1-10, but some of them still recognize 1-4 numbers.

(5) Main product revisions. In this stage, The writers are suggested to make a colorful background of domino card Based on preliminary field testing result and classroom teacher.

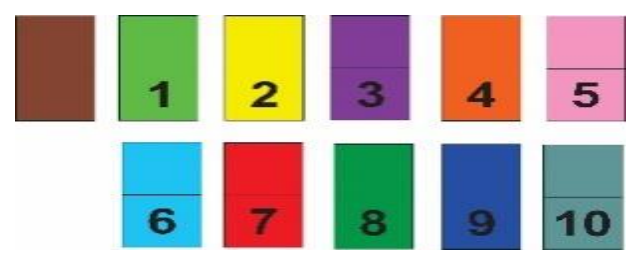

Figure 3. Revision of Domino Card

(6) The main field testing. There were 15 children tested in RA MNU 145 and 15 children of Group A in MNU RA 68. It was found that children's ability to recognize symbols of number 1-10 incresed after the used of numeric domino game although there were still some of them only recognized number 1-4. The ability of children to recognize the symbols of number 1-10 increased from preliminary to main field testing. The following graph shows increasing values:

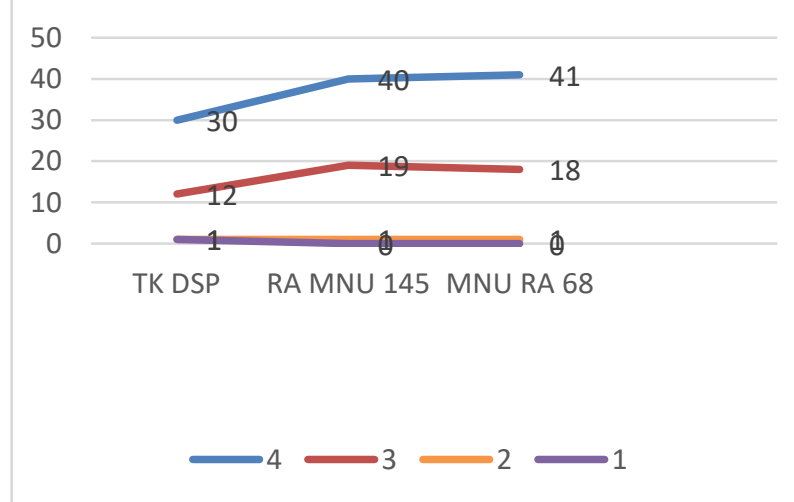

Graph 2. Result Comperation on Preliminary and Main Field Testing using Numerical Domino Game 
(7) Operational product revision. The writers were suggested by classroom teachers to revise the product after the main field testing in the class. The revision that is suggested the packaging of domino card products in line with way theare played.

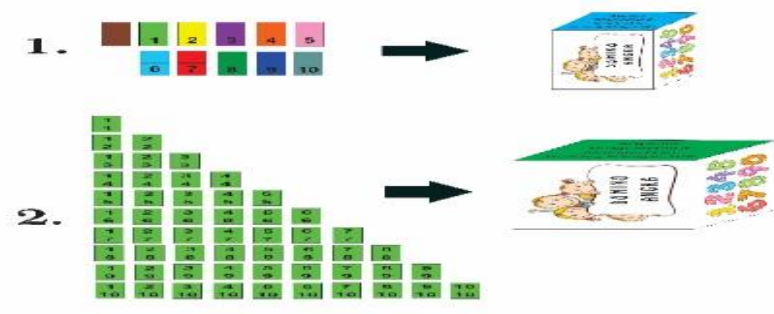

Figure 4. Revision of Packanging

(8) The operational field Testing. There were 14 children tested in MTK NU 231, 16 children in MNU TK 71, and 18 children in MNU MHS 119. It was found that there was the increasing ability of children aged 4-5 year to recognize the symbol of numbers. The average score of MTK NU 231, was 0.80, categorized as high, MNU TK 71 was 0.85 , categorized as high. And MNU MHS 119 was 0.87 , also categorized as high.

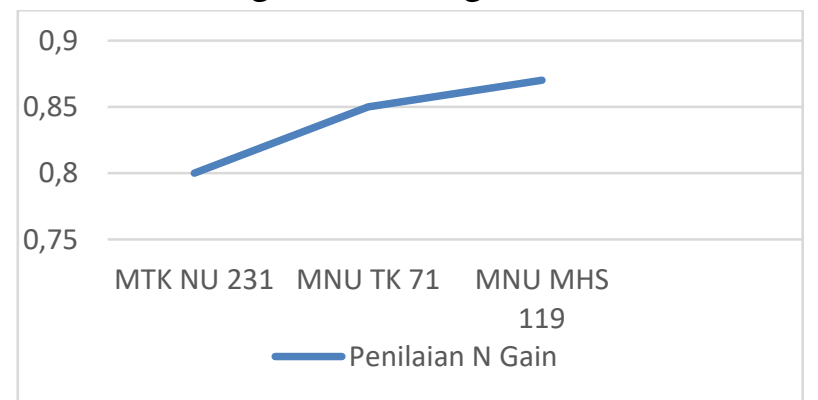

\section{Graph 3. Result Comparison of Numeric Domino Game Using N Gain Test}

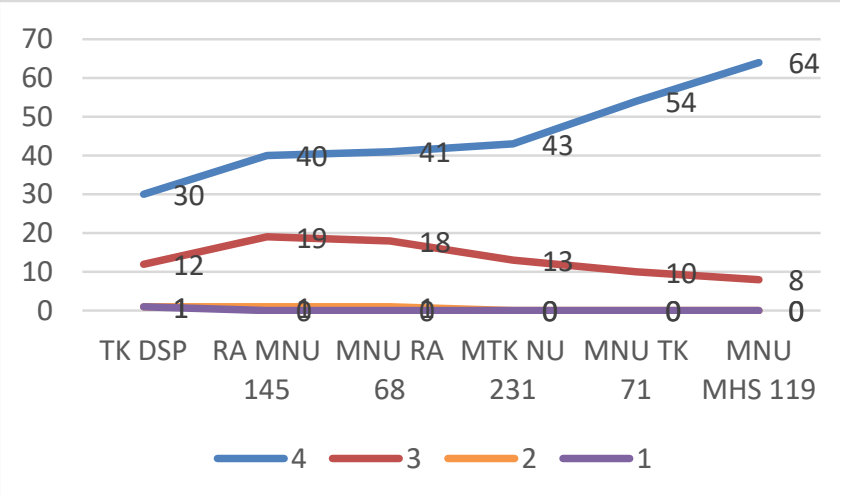

Graph 4. Result Comparison of Preliminary, Main and Operational Testing in Numeric Domino Game

Graph 4 shows, there is an increase in the results of the ability to recognize the symbols of numbers 1-10 in children by using number domino games. The use of a game in this study is supported by research conducted by Banavides et al., (2016) which explains, the game is one of the activities that can improve children's cognitive skills.

(9) Final product revision. here, numeric domino game prototype is feasible and effective to be used in learning activities to recognize the symbols of number 1-10 in children aged $4-5$ years.

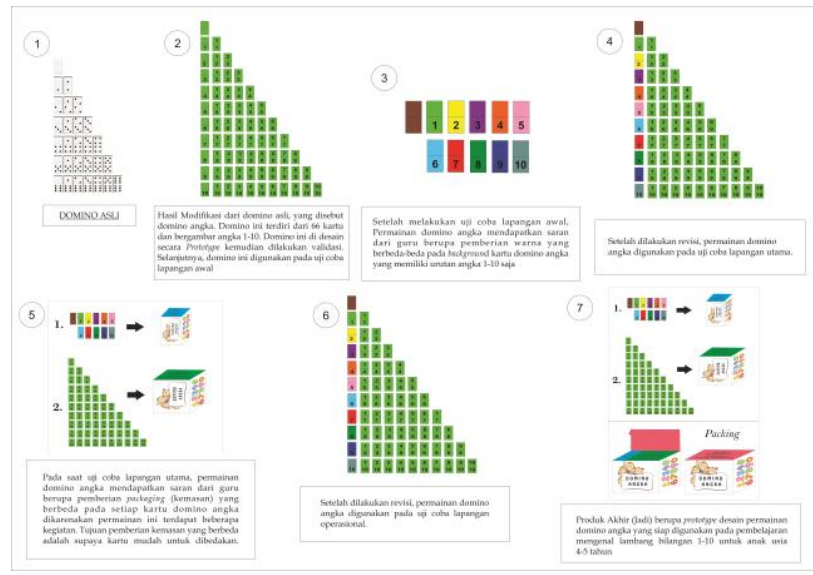

Figure 5. The Product of Numerical Domino

\section{Game}

From the previous discussion, it can be said that the developed numeric domino game can increase the ability of children aged 4-5 years to recognize the symbols of numbers 110. Children aged 4-5 years are in the preoperational stage, who should be able to think systematically about concrete objects. Children should have begun to develop symbols with objects and also learn through mental images and images from his memories. The children's cognitive abilities in recognizing the symbol of numbers can be stimulated by numeric domino games.

Docket \& Fleer (2000) state that through playing game, children can find their world as well as sensory exercises in learning to think. the previous research conducted by Brankaer et al. (2014) also uses numeric domino games in learning, except that the learning focuses on understanding the numbers for children with special needs, namely children with mild intellectual disabilities. another research conducted by Santos \& Alves (2000) explained that through numeric domino games, children can build their knowledge because when playing dominoes children are taught to recognize concepts, recognize rules, and interact directly.

The link between the previous research and opinions above prove that the numeric domino game is feasible and effective to be 
used as an interesting game to improve the ability to recognize the symbols of number 1 10 in children aged 4-5 years in kindergarten.

\section{CONCLUSION}

This developmental research produced a prototype of numeric domino game adapted from domino game. This game is is categorized as "feasible and effective" to be used as an interesting game in learning to recognize the symbols of numbers $1-10$. Thus, it can be concluded that after the use of numeric domino game, the ability of children to recognize symbols 1-10 numbers is categorized as high category. The average score of MTK NU 231, was 0.80, categorized as high, MNU TK 71 was 0.85 , categorized as high, and MNU MHS 119 was 0.87, also , categorized as high. Therefore, it can be concluded that the numeric domino game is feasible and effective game used as learning to recognize the symbol of numbers 1-10 in children aged 4-5 years (group A).

\section{ACKNOWLEDGMENT}

The researchers would like to thank colleagues who have been willing to share their knowledge during the course of the study. In addition, the deepest gratitude is given to all partner school principals who kindly allowed researchers to conduct research at their institutions.

\section{REFERENCE}

Anderson \& Bailey. 2010. The Importance of Play in Early Childhood Development. Article. U.S: Montana State University.

Banavides, et.al. 2016. "Numerical Activities and Information Learnedat Home Link to the Exact Numeracy Skills in 5-6 Years-Old Children”. Original Research. Vol. 7 (94).

Bergen. 2002.The Role of Pretend Play in Children's Cognitive Development. Journal. Oxford: Miami University

Borg, W.R., Gall, J.P. \& Gall, M.D. 2003. Educational Research An Introduction, Seventh Edition. Boston: Pearson Education.
Brankaer, et.al. 2014. The Effect Of A Numerical Domino Game On Numerical Magnitude Processing In Children With Mild Intellectual Disabilities. Article. Belgium: KU Leuven.

Creswell, John W. 2012. Educational Research : Planning, Conducting, and Evaluating Quantitative and Qualitative Research. 4th Edition. Boston: Pearson Education.

Docket \& Fleer. 2000. Play and Pedagogy in Early Childhood Bending The Rules. Sydney: Harcourt.

Fauziddin M. \& Mufarizuddin. 2018. Useful of Clap Hand Games for Optimalize Cognitive Aspects in Early Childhood Education. Jurnal Obsesi : Jurnal Pendidikan Anak Usia Dini. Vol 2 (2) 162-169.

Hake, R. R. 1998. Analyzing Change-Gain Scores. American Educational Research Methodology.

Kennedy \& Barblett. 2010. Learning and Teaching Through Play. Australia: Early Childhood Australia.

Leeuwen, Fred van. 2010. Early Childhood Education: A Global Scenario. Education International.

Lillard, Angeline S. 2013. Playful Learning and Montessori Education. Journal. American: American Journal of Play.

Santos \& Alves. 2000. Dominos as an Interactive Context for the Construction of Knowledge by Preschool Children. Article. Portuguese: Universidade Federal do Pará.

Tatminingsih S. 2019. Alternative Stimulasi Kemampuan Kognitif melalui Penerapan Modul Pembelajaran Berbasis Permainan Komprehensif. Jurnal Obsesi : Jurnal Pendidikan Anak Usia Dini. Vol 3 (1) 183-190.

UNESCO \& UNICEF. 2012. Early Childhood Care and Education. Bangkok: UNESCO UNICEF.

Wang, Zhenlin.2010. Kindergarten Children's Number Sense Development Through Board Game. Article. Hongkong: Institute of Education 